\title{
Prevention and Treatment of Phlebitis Secondary to the Insertion of a Peripheral Venous Catheter: A Scoping Review from a Nursing Perspective
}

\author{
Aitana Guanche-Sicilia ${ }^{1,+}$, María Begoña Sánchez-Gómez ${ }^{2, \dagger}$, María Elisa Castro-Peraza ${ }^{2}{ }^{\mathbb{D}}$, \\ José Ángel Rodríguez-Gómez ${ }^{3}$, Juan Gómez-Salgado ${ }^{4,5, *(\mathbb{D})}$ and Gonzalo Duarte-Clíments ${ }^{2}$ \\ check for \\ 1 University Hospital Nuestra Señora de Candelaria, Canary Islands Health Service, 38010 Tenerife, Spain; \\ aitanaguanche@gmail.com \\ 2 University School of Nursing Nuestra Señora de Candelaria, University of La Laguna, 38001 Tenerife, Spain; \\ extmsanchez@ull.edu.es (M.B.S.-G.); mcastrop@ull.edu.es (M.E.C.-P.); extgduartcl@ull.edu.es (G.D.-C.) \\ 3 Chair of Nursing, Faculty of Health Sciences, University of La Laguna, 38001 Tenerife, Spain; \\ jarogo@ull.edu.es \\ 4 Department of Sociology, Social Work and Public Health. Faculty of Labour Sciences, University of Huelva, \\ 21007 Huelva, Spain \\ 5 Safety and Health Postgraduate Programme, Universidad Espíritu Santo, 092301 Guayaquil, Ecuador \\ * Correspondence: jgsalgad@gmail.com; Tel.: +34-959219700 \\ + These authors are co-first authors, as they contributed equally to this work.
} updates

Citation: Guanche-Sicilia, A.; Sánchez-Gómez, M.B.; Castro-Peraza, M.E.; Rodríguez-Gómez, J.Á.; GómezSalgado, J.; Duarte-Clíments, G. Prevention and Treatment of Phlebitis Secondary to the Insertion of a Peripheral Venous Catheter: A Scoping Review from a Nursing Perspective. Healthcare 2021, 9, 611. https://doi.org/10.3390/healthcare 9050611

Academic Editors: Francesco Cacciatore and Akira Sekikawa

Received: 3 March 2021

Accepted: 14 May 2021

Published: 19 May 2021

Publisher's Note: MDPI stays neutral with regard to jurisdictional claims in published maps and institutional affiliations.

Copyright: (c) 2021 by the authors. Licensee MDPI, Basel, Switzerland. This article is an open access article distributed under the terms and conditions of the Creative Commons Attribution (CC BY) license (https:/ / creativecommons.org/licenses/by/ $4.0 /)$.

\begin{abstract}
The objective of this work was to identify available evidence on nursing interventions for the prevention and treatment of phlebitis secondary to the insertion of a peripheral venous catheter. For this, a scoping systematic review was carried out following the guidelines in the PRISMA declaration of documents published between January 2015 and December 2020. The search took place between December 2020 and January 2021. Scielo, Pubmed, Medline, Scopus, WOS, CINHAL, LILACS, and Dialnet databases were consulted, and CASPe, AGREE, and HICPAC tools were used for the critical reading. A total of 52 studies were included to analyze nursing interventions for treatment and prevention. Nursing interventions to prevent phlebitis and ensure a proper catheter use included those related to the maintenance of intravenous therapy, asepsis, and choosing the dressing. With regard to the nursing interventions to treat phlebitis, these were focused on vigilance and caring and also on the use of medical treatment protocols. For the prevention of phlebitis, the highest rated evidence regarding asepsis include the topical use of $>0.5 \%$ chlorhexidine preparation with $70 \%$ alcohol or $2 \%$ aqueous chlorhexidine, a proper hygienic hand washing, and the use clean gloves to handle connections and devices. Actions that promote the efficacy and safety of intravenous therapy include maintenance of venous access, infusion volume control, verification of signs of phlebitis during saline solution and medication administration, and constant monitoring. It is recommended to remove any catheter that is not essential. Once discharged from hospital, it will be necessary to warn the patient about signs of phlebitis after PVC removal.
\end{abstract}

Keywords: phlebitis; catheters; nursing care; patient-centered care; patient safety; evidence-based practice

\section{Introduction}

Vascular access cannulation through the use of peripheral venous catheters (PVCs) is a common practice and is considered the most common invasive procedure performed on hospitalized patients [1]. This technique allows quick access to the vascular system, being less invasive and less complex than other techniques [1-3]. The type of catheter is chosen based on the estimated duration and type of treatment to be infused, and among the uses of PVCs are fluid therapy, parenteral nutrition, blood products, and diagnostic tests [4].

The most common side effect of PVC is phlebitis [5]. This consists of acute inflammation of the wall of the blood vessels, with irritation of the venous endothelium in the section 
or segment cannulated by the catheter [6]. Identification of phlebitis requires assessment of possible signs and symptoms present in the insertion area, such as erythema, tumefaction in the vein, pain, heat, and fever [7]. In this sense, the use of rating scales such as the Visual Infusion Phlebitis (VIP) scale, the Phlebitis scale, and the Maddox scale [8-10] may be useful.

In Spain, up to $30 \%$ of the bacteriaemia associated with hospital care is related to the use of intravascular devices, and these produce increased morbidity and hospital expenses, which are estimated at around 18,000 euros per episode [4].

PVC management is an under-recognized issue regarding patient risk within the complexity of care [11]. It was verified through the National Study of Adverse Events (ENEAS, for its acronym in Spanish) that if phlebitis is included as an adverse healthcare event, it would rank first followed by medication errors, infections arising from healthcarerelated practices, and surgical techniques [7]. On the other hand, the SENECA Project: Quality of care standards for patient safety in National Health System hospitals, enabled from 1344 revised medical records, from 32 different hospitals, identified approximately 377 patients who developed phlebitis and/or extravasation (25.1\%) [7]. Phlebitis prolongs hospitalization and treatment, increases economic expenses, decreases patient satisfaction, and can lead to other complications such as sepsis, pain, discomfort, stress, possibility of clotting, thrombophlebitis, and embolism [5,12,13].

The Infusion Nurses Society (INS) [9] indicates that the accepted phlebitis rate should be $5 \%$ or less $[14,15]$. Currently, a phlebitis incidence of $0.5 \%$ to $59.1 \%$ [5] is estimated, with a prevalence of between 20 and $80 \%$ of patients following intravenous treatment [16].

Nurses' knowledge on the proper management of PVC and early recognition of risk factors can reduce these complications [14,17]. In Spain, it is a nursing competence, collected in Order CIN/2134/2008, of 3 July [18]. In addition, the North American Nursing Diagnosis Association (NANDA-I) collects a risk diagnosis to prevent risk of (00213) phlebitis, and the Nursing Intervention Classification (NIC) establishes interventions for the prevention and treatment of phlebitis such as (4200) Intravenous therapy (iv); (2314) Medication administration: intravenous (iv); and (4235) Phlebotomy: Cannulated Vessel $[19,20]$.

For this reason, the objective of this review was to identify available evidence on nursing interventions for the prevention and treatment of phlebitis secondary to the insertion of a peripheral venous catheter.

\section{Materials and Methods}

\subsection{Design}

A systematic scoping review [21] of the literature was carried out, following the standards set out in the PRISMA extension for Scoping Reviews (PRISMA-ScR) [22]. Based on the PICO format (Table 1), the following research question was developed: What are the evidence-based nursing interventions for the prevention and treatment of phlebitis in patients with PVC?

Table 1. PICO.

\begin{tabular}{|c|c|}
\hline Patient & Patients with Peripheral Venous Catheter \\
\hline Intervention & $\begin{array}{c}\text { Evidence-based nursing interventions for the prevention and treatment } \\
\text { of phlebitis }\end{array}$ \\
\hline Comparison & Non-evidence-based routine interventions \\
\hline Outcomes & $\begin{array}{l}\text { Use of sterile and transparent dressing, catheter size, use of hot and cold } \\
\text { compresses, topical treatment, management and maintenance of } \\
\text { intravenous therapy }\end{array}$ \\
\hline
\end{tabular}




\subsection{Search Strategy}

The search was performed between December 2020 and January 2021 (Table 2). The databases consulted were Scielo, Pubmed, Medline, Scopus, WOS, CINHAL, LILACS, and Dialnet using MeSH and DeCS descriptors (Table 2).

Table 2. Search strategy.

\begin{tabular}{|c|c|c|c|c|}
\hline Database & $\begin{array}{c}\text { Date } \\
(\mathrm{dd} / \mathrm{mm} / \mathrm{yyyy})\end{array}$ & Search Strategy & Found Articles & Pre-Selected Articles \\
\hline Scielo & $7 / 12 / 2020$ & Phlebitis AND catheter & 19 & 10 \\
\hline Scielo & $02 / 01 / 2021$ & Phlebitis AND treatment & 5 & 1 \\
\hline Scopus & $7 / 12 / 2020$ & Phlebitis and nurs* & 20 & 6 \\
\hline Scopus & $02 / 01 / 2021$ & Phlebitis AND treatment & 6 & 1 \\
\hline Pubmed & $2 / 12 / 2020$ & Phlebitis and nurs* & 20 & 6 \\
\hline Pubmed & $12 / 12 / 2020$ & Phlebitis AND intervention AND nurs* & 2 & 1 \\
\hline Pubmed & $21 / 12 / 2020$ & Phlebitis AND nurs* intervention & 17 & 2 \\
\hline Pubmed & $21 / 12 / 2020$ & Phlebitis AND assessment measure & 1 & 1 \\
\hline Pubmed & $13 / 01 / 2021$ & Phlebitis AND prevention AND nurs* & 5 & 1 \\
\hline Pubmed & $25 / 11 / 2020$ & Competence AND nurs* AND phlebitis & 13 & 5 \\
\hline Dialnet & $13 / 12 / 2020$ & Phlebitis AND nursing & 13 & 3 \\
\hline Medline & $13 / 12 / 2020$ & Phlebitis and nursing interventions & 2 & 2 \\
\hline Medline & $19 / 12 / 2020$ & Phlebitis and nurs* & 64 & 8 \\
\hline Medline & $19 / 12 / 2020$ & $\begin{array}{l}\text { Phlebitis AND treatment OR } \\
\text { intervention OR therapy AND nurs* }\end{array}$ & 41 & 2 \\
\hline WOS & $21 / 01 / 2021$ & Phlebitis AND nurs* AND prevention & 15 & 5 \\
\hline WOS & $21 / 01 / 2021$ & Phlebitis AND treatment AND nurs* & 15 & 2 \\
\hline LILACS & $21 / 12 / 2020$ & Phlebitis AND nursing & 65 & 8 \\
\hline LILACS & $21 / 12 / 2020$ & Phlebitis and intervention & 3 & 1 \\
\hline CINHAL & $02 / 01 / 2021$ & $\begin{array}{l}\text { Phlebitis AND treatment OR } \\
\text { intervention OR therapy AND nurs* }\end{array}$ & 27 & 5 \\
\hline CINAHL & $02 / 01 / 2021$ & Phlebitis AND intervention & 23 & 1 \\
\hline Total & & & 376 & 71 \\
\hline
\end{tabular}

\subsection{Selection Criteria}

The search was limited to full-text documents, in Spanish, English, and/or Portuguese, published in the last 5 years. These included empirical studies and clinical guidelines that focused on phlebitis, its classification, diagnosis, prevention, and treatment from the nursing competence perspective. Those that, during the critical reading, did not meet the expected criteria in the first three questions of the CASPe [23] tool nor of Berra et al.'s instrument [24] for descriptive articles were excluded. Articles not available in full text and published in languages other than Spanish, English, or Portuguese were also excluded.

Following the recommendations for improvement for Scoping Reviews by Levac, Colquon, and O'Brien [25], it was decided not to discriminate by type of study in the selection. In the classification and presentation of results, we differentiate according to the design of the selected studies.

\subsection{Data Collection and Extraction}

The search was conducted independently and pooled by the researchers as detailed in the Authors Contributions. The authors performed an evidence synthesis by peer evaluation, analyzing each intervention and evidence individually, following the criteria provided by the Joanna Briggs Institute (JBI). The discrepancies were jointly discussed to reach consensus on the degree of evidence (DE) and the degree of recommendation (DR). 


\subsection{Evaluation of Methodological Quality}

Once the titles and summaries of the articles were critically read, data were classified according to the objectives of the study. The included full-text articles were assessed with the CASPe [23] and Berra et al.'s [24] tools. For clinical practice guidelines, AGREE [26] was used for critical reading and the HICPAC system for evidence synthesis [27]. The JBI [28] criteria were used to classify the degree of evidence (DE) and the degree of recommendation (DR) of nursing interventions.

\section{Results}

The number of records identified in the databases was 376, to which five more records were added by referential search to introduce the clinical practice guidelines, for a total of 381 references. Of the 381 identified references, 52 studies were finally selected according to eligibility criteria (Figure 1) [22].
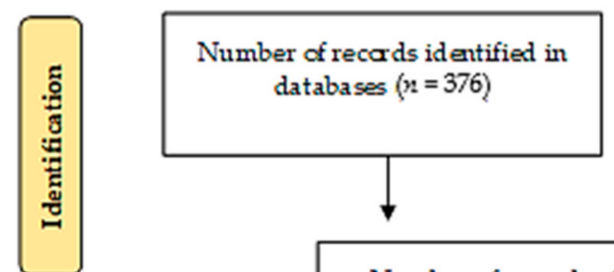

Number of recards after eliminating duplicates $(n=342)$
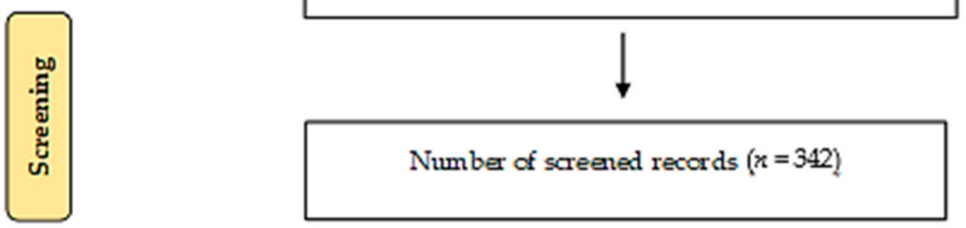

Number of screened records $(n=342)$
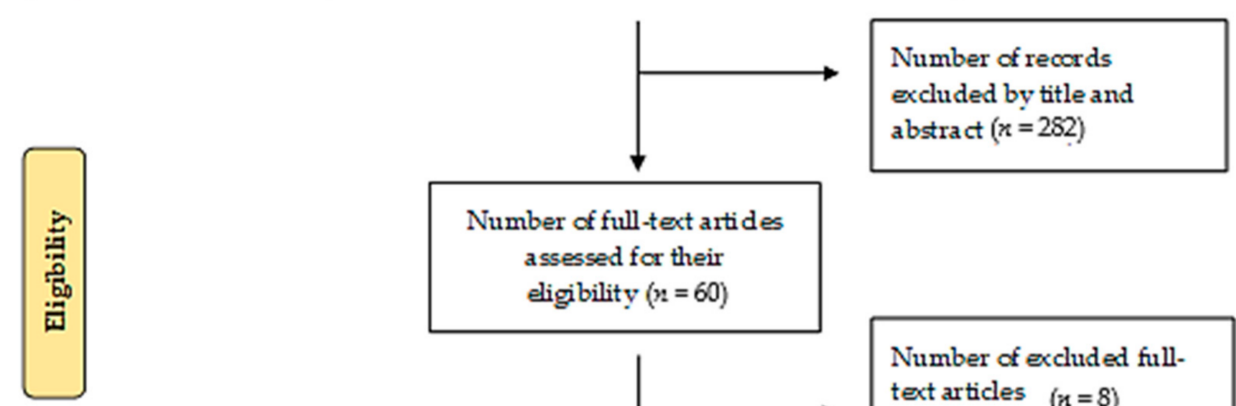

Number of full-text artides assessed for their eligibility $(n=60)$

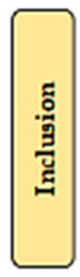

Tctalincluded studies

Number of additional records identified in other sour ces and referencial search $(n=5)$

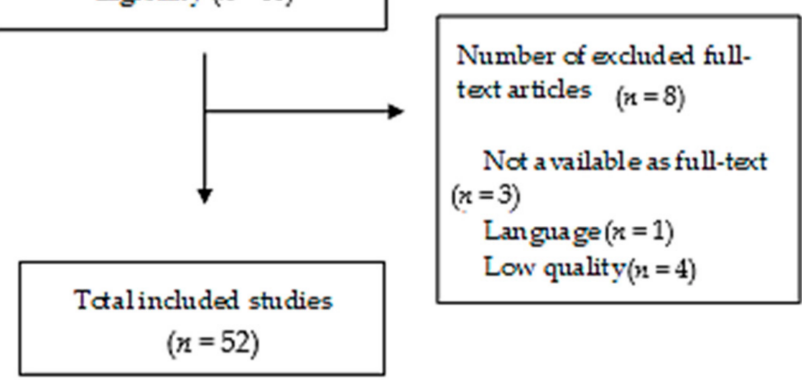

Figure 1. Search results (PRISMA flowchart).

In terms of typology, 9 randomized clinical trials, 17 cohort studies, 8 systematic reviews, 3 case and control studies, 1 qualitative study, 10 descriptive studies, and 4 clinical practice guidelines, out of the total of 52 selected studies were included. Table 3 lists the characteristics of the studies included in the scoping review classified according to the type of article. 
Table 3. Characteristics of the studies included in the scoping review.

\section{a. RESULTS FROM CLINICAL STUDIES}

\begin{tabular}{|c|c|c|c|c|c|}
\hline Year and Author & Objective & Type of Study & Results & Critical Reading & $\begin{array}{l}\text { JBI Synthesis of } \\
\text { the Evidence }\end{array}$ \\
\hline $\begin{array}{l}\text { Reichembach-Danski et al., } \\
2016 \text { [29] }\end{array}$ & $\begin{array}{l}\text { Evaluate the incidence of } \\
\text { complications related to } \\
\text { peripheral intravenous } \\
\text { catheter use in neonates and } \\
\text { identify associated risk factors. }\end{array}$ & Prospective cohort study & $\begin{array}{l}\text { Protocols with measures such as } \\
\text { continuous observation of the insertion } \\
\text { site, keeping the catheter insertion site } \\
\text { visible, and saline solution infusion prior } \\
\text { to the administration of other substances } \\
\text { may be used to reduce complications. }\end{array}$ & $9 / 11^{* * * *}$ & $\mathrm{DE}^{*}: 3 \mathrm{c}$ DR: $\mathrm{A}$ \\
\hline Braga et al., 2018 [30] & $\begin{array}{l}\text { Determine the incidence rate } \\
\text { and risk factors for phlebitis } \\
\text { and infiltration in patients } \\
\text { with peripheral } \\
\text { venous catheter. }\end{array}$ & Cohort study & $\begin{array}{l}\text { To improve quality of care and prevent } \\
\text { phlebitis and infiltrations, the nurse } \\
\text { should analyze patient characteristics, } \\
\text { prescribed intravenous medications } \\
\text { (irritant and/or vesicant, pH, and } \\
\text { osmolarity), expected duration of } \\
\text { intravenous treatment, and risk factors } \\
\text { for complications that can occur before } \\
\text { selecting a venous catheter. Evaluate } \\
\text { risks and benefits of each type of } \\
\text { catheter and consider patient } \\
\text { preferences. This test may indicate the } \\
\text { use of other venous catheters, such as } \\
\text { peripherally inserted central catheter. }\end{array}$ & $9 / 11^{* * * *}$ & $\mathrm{DE}^{*}: 3 \mathrm{c}$ DR: $\mathrm{A}$ \\
\hline $\begin{array}{c}\text { Rosário-Pereira et al., } 2019 \\
\text { [31] }\end{array}$ & $\begin{array}{l}\text { Describe cases of phlebitis } \\
\text { reported in a university } \\
\text { hospital and contribute to } \\
\text { possible improvement actions } \\
\text { in quality of care and safety. }\end{array}$ & $\begin{array}{l}\text { Retrospective, } \\
\text { observational study }\end{array}$ & $\begin{array}{l}\text { Knowing the characteristics of phlebitis } \\
\text { favors understanding and minimization } \\
\text { of this adverse event so as to establish } \\
\text { preventive behaviors and decrease risk } \\
\text { and incidence. }\end{array}$ & $\underset{* * * * *}{\text { Intermediate evidence }}$ & $\mathrm{DE}^{*}: 3 \mathrm{e}$ DR: $\mathrm{A}$ \\
\hline Lim et al., 2018 [32] & $\begin{array}{l}\text { Project to improve visibility of } \\
\text { intravenous area through the } \\
\text { use of transparent adhesive } \\
\text { dressings to achieve frequent } \\
\text { and adequate intravenous } \\
\text { inspection of the intravenous } \\
\text { area and reduce incidence } \\
\text { of complications. }\end{array}$ & Quasi-experimental study & $\begin{array}{l}\text { Improved visibility of the intravenous } \\
\text { puncture site and nurses' compliance in } \\
\text { frequent testing and monitoring; } \\
\text { phlebitis can be detected early, reducing } \\
\text { severity of complications. }\end{array}$ & $8 / 11^{* * * *}$ & $\mathrm{DE}^{*}:$ 2d DR: B \\
\hline
\end{tabular}


Table 3. Cont.

\begin{tabular}{|c|c|c|c|c|c|}
\hline Bugden et al., 2016 [33] & $\begin{array}{l}\text { Assess whether the use of a } \\
\text { skin adhesive glue to secure a } \\
\text { peripheral intravenous line } \\
\text { improves failure rates } \\
\text { compared with standard } \\
\text { securing measures }\end{array}$ & Randomized clinical trial & $\begin{array}{l}\text { Adding a drop of cyanoacrylate } \\
\text { adhesive helps stabilize the peripheral } \\
\text { intravenous catheter. }\end{array}$ & $9 / 11^{* * * *}$ & $\mathrm{DE}^{*}: 1 c \mathrm{DR}: \mathrm{A}$ \\
\hline Büyükyılmaz et al., 2019 [34] & $\begin{array}{l}\text { Evaluate efficacy of I.V } \\
\text { UltraDressing to protect } \\
\text { peripheral intravenous } \\
\text { catheters in pediatric patients. }\end{array}$ & Randomized clinical trial & $\begin{array}{l}\text { I.V House UltraDressing device is useful } \\
\text { to increase catheter dwell time and } \\
\text { protect and stabilize PVCs in } \\
\text { pediatric patients. }\end{array}$ & $9 / 11^{* * * *}$ & DE*: 1c DR: A \\
\hline Annisa et al., 2017 [35] & $\begin{array}{l}\text { Assess the effectiveness of } \\
\text { applying hot compress to } \\
\text { reduce the degree of phlebitis. }\end{array}$ & Quasi-experimental study & $\begin{array}{l}\text { A hot water compress is useful in the } \\
\text { treatment of phlebitis and could } \\
\text { decrease degree of phlebitis in an } \\
\text { effective and cost-saving way. }\end{array}$ & $8 / 11^{* * * *}$ & $\mathrm{DE}^{*}: 2 \mathrm{~d}$ DR: $\mathrm{A}$ \\
\hline $\begin{array}{l}\text { Bigdeli-Shamloo et al., } \\
2019 \text { [36] }\end{array}$ & $\begin{array}{l}\text { Assess the effects of topical } \\
\text { sesame oil on reduced severity } \\
\text { of "chemotherapy-induced } \\
\text { phlebitis" pain. }\end{array}$ & Randomized clinical trial & $\begin{array}{l}\text { Complementary methods for the } \\
\text { treatment of phlebitis symptoms are } \\
\text { proposed. Application of sesame oil is } \\
\text { effective in reducing severity of } \\
\text { chemotherapy-induced phlebitis pain. }\end{array}$ & $9 / 11^{* * * *}$ & $\mathrm{DE}^{*}: 1 c \mathrm{DR}: \mathrm{A}$ \\
\hline Sharifi-Ardani et al., 2017 [37] & $\begin{array}{l}\text { Assess the effect of topical } \\
\text { chamomile on phlebitis caused } \\
\text { by the administration of } \\
\text { amiodarone infusion in PVC. }\end{array}$ & Randomized clinical trial & $\begin{array}{l}\text { Topical chamomile may be effective in } \\
\text { decreasing incidence of phlebitis for its } \\
\text { anti-inflammatory capacity. }\end{array}$ & $9 / 11^{* * * *}$ & $\mathrm{DE}^{*}: 1 \mathrm{c}$ DR: $\mathrm{A}$ \\
\hline $\begin{array}{l}\text { García-Quintanilla et al., } \\
\qquad 2018 \text { [38] }\end{array}$ & $\begin{array}{l}\text { Describe the use and assess } \\
\text { the efficacy and safety of } \\
\text { Burow solution for topical } \\
\text { treatment of phlebitis. }\end{array}$ & $\begin{array}{l}\text { Prospective observational } \\
\text { study }\end{array}$ & $\begin{array}{l}\text { During the inclusion period for Burow } \\
\text { solution in } 35 \text { patients with phlebitis, } 12 \\
\text { have been excluded for lack of follow-up. } \\
83 \%(\mathrm{n}=19) \text { have responded to the } \\
\text { therapy by reducing the degree of } \\
\text { phlebitis by two points after three days } \\
\text { of treatment, and } 17 \%(\mathrm{n}=4) \text { were } \\
\text { unresponsive, requiring topical } \\
\text { applications of Feparil@. }\end{array}$ & $7 / 11^{* * * *}$ & $\mathrm{DE}^{*}: 3 \mathrm{e}$ DR: $\mathrm{A}$ \\
\hline
\end{tabular}


Table 3. Cont

\begin{tabular}{|c|c|c|c|c|c|}
\hline Jourabloo et al., 2017 [39] & $\begin{array}{l}\text { Compare the effect of wet } \\
\text { compresses and marigold } \\
\text { ointment on the severity of } \\
\text { phlebitis caused by } \\
\text { dextrose infusion. }\end{array}$ & Randomized clinical trial & $\begin{array}{l}\text { Applying marigold ointment decreased } \\
\text { the severity of phlebitis in a shorter } \\
\text { period, compared to using a wet, hot } \\
\text { compress. This ointment is } \\
\text { recommended to reduce } \\
\text { phlebitis severity. }\end{array}$ & $9 / 11^{* * * *}$ & $\mathrm{DE}^{*}: 1 \mathrm{c} \mathrm{DR}: \mathrm{A}$ \\
\hline Parreira et al., 2020 [40] & $\begin{array}{l}\text { Establish clinical efficacy and } \\
\text { safety parameters for } \\
\text { double-pump syringes for } \\
\text { intravenous medication } \\
\text { administration and } \\
\text { PVC washing. }\end{array}$ & Randomized clinical trial & $\begin{array}{l}\text { Developing a double-pump syringe } \\
\text { makes it easier for nurses to adopt good } \\
\text { clinical practices in procedures and } \\
\text { administer intravenous medicine to } \\
\text { reduce catheter handling. }\end{array}$ & $8 / 11^{* * * *}$ & $\begin{array}{l}\text { DE: } 1 c^{*} \\
\text { DR: A }\end{array}$ \\
\hline Pérez-Granda et al., 2020 [41] & $\begin{array}{l}\text { Compare rates of phlebitis and } \\
\text { catheter tip colonization } \\
\text { between PVC blocked with } \\
\text { saline solution and blocked } \\
\text { with heparin in patients } \\
\text { admitted to internal medicine. }\end{array}$ & Randomized clinical trial & $\begin{array}{l}\text { No statistically significant differences } \\
\text { were found in frequency of phlebitis and } \\
\text { PVC tip colonisation regarding blockage } \\
\text { with saline solution or with heparin. } \\
\text { PVC can be maintained with saline } \\
\text { solution, and it is safer and cheaper } \\
\text { than heparin. }\end{array}$ & $8 / 11^{* * * *}$ & $\begin{array}{l}\text { DE: } 1 c^{*} \\
\text { DR: A }\end{array}$ \\
\hline \multicolumn{6}{|c|}{ b. RESULTS FROM REVIEWS } \\
\hline Year and Author & Research Question & Methodology & Results & Critical Reading & $\begin{array}{l}\text { JBI Synthesis of } \\
\text { the Evidence }\end{array}$ \\
\hline Higgingson, 2015 [42] & $\begin{array}{l}\text { Assess complications } \\
\text { associated with improperly } \\
\text { secured intravenous cannulae, } \\
\text { along with examination of } \\
\text { fastening devices. }\end{array}$ & Literature review & $\begin{array}{l}\text { Intravenous catheters not secured } \\
\text { properly produce higher rates of } \\
\text { mechanical phlebitis and infection. } \\
\text { Clinical staff need to be educated on } \\
\text { PVC stabilization as an important } \\
\text { measure to reduce phlebitis. Safety } \\
\text { devices are available for their use } \\
\text { whenever appropriate. }\end{array}$ & $8 / 11^{* * * *}$ & $\begin{array}{c}\mathrm{DE}^{*}: 4 \mathrm{a} \\
\text { DR: } \mathrm{A}\end{array}$ \\
\hline
\end{tabular}


Table 3. Cont.

\section{Provide summarized evidence
on intravascular device on intravascular device
management to reduce risk of infection.}

Continuous training and evaluation are needed on handling, aseptic technique and hand washing, choosing a catheter based on estimated function, duration, and complications.
Recommended ***

DR: A *

Provide summarized evidence on intravascular device

Chau and Pellowe, 2008 [43] $\quad \begin{gathered}\text { on intravascular device } \\ \text { management to reduce risk }\end{gathered}$ information sheet

Best practice of infection.

Flush stopcocks with saline solution.

Recommended ***

$\mathrm{DR} \cdot \mathrm{B}$ *

Effectiveness of topical treatments in hospitalized patients with phlebitis

Martín-Gil et al., 2017 [6] secondary to periphera venous catheterisation to improve or resolve signs and symptoms.

Aloe vera, notoginseny, diclofenac, and heparin gel $1000 \mathrm{IU}$ showed a level of evidence and a moderate degree of recommendation. Heparin gel is the only

Systematic review of clinical trials and reviews compound indicated by the Spanish Agency of Medicines and Medical

Products to treat post-infusion phlebitis;

notoginseny is not marketed in the

Western world; and diclofenac is an anti-inflammatory used in various pathologies.

\section{c. RESULTS FROM QUALITATIVE STUDIES}

\begin{tabular}{|c|c|c|c|c|c|}
\hline Year and Author & Research Question & Methodology & Results & Critical Reading & $\begin{array}{l}\text { JBI Synthesis of the } \\
\text { Evidence }\end{array}$ \\
\hline $\begin{array}{l}\text { Salgueiro-Oliveira et al., } \\
2019 \text { [2] }\end{array}$ & $\begin{array}{l}\text { What are the PVC-related } \\
\text { nursing practices for } \\
\text { identifying deviations from } \\
\text { available evidence on } \\
\text { phlebitis prevention? }\end{array}$ & $\begin{array}{c}\text { Qualitative study, } \\
\text { participants monitoring } \\
\text { and interviews }\end{array}$ & $\begin{array}{l}\text { Nursing practices that differ from } \\
\text { scientific evidence; influence from } \\
\text { institutional dimensions; characteristics } \\
\text { of the sick and misinformation about } \\
\text { patient safety risk actions. Developing } \\
\text { protocols and implementing continuing } \\
\text { education are critical to acquiring skills, } \\
\text { correcting and providing safe and } \\
\text { quality assistance. }\end{array}$ & $9 / 11^{* * * *}$ & $\begin{array}{l}\text { DE*: } 4 b \\
\text { DR: A }\end{array}$ \\
\hline
\end{tabular}


Table 3. Cont.

\section{d. RESULTS FROM DESCRIPTIVE STUDIES}

Year and Author
Research Question

\section{Results}

For the prevention of phlebitis, an educational intervention through team training has the potential to reduce $50 \%$

of cases in peripheral intravenous

therapy. Phlebitis rates/incidence are used as an indicator of nursing quality of care. As best prevention practices, it is suggested to use smaller calibre cannulae, transparent dressings, and professional knowledge of signs and symptoms that warn of possible

What are the characteristics of Da Silva-Oliveira et al, phlebitis reported in a hospital 2016 [44]
Descriptive quantitative study phlebitis. On the venous access site, a statistical association was found between the back of the hand with more grade I phlebitis, followed by antecubital pit with higher number of grade II and grade III phlebitis. It is advisable to prioritize peripheral catheterisation in upper limb blood vessels, as they are safer. Avoid joint areas with greater mobility, more prone to traumatic mechanical phlebitis formation, and control osmolarity and $\mathrm{pH}$ of medication to reduce chemical phlebitis.

\section{Critical Reading}

JBI Synthesis of the Evidence

HIGH evidence *****

$\mathrm{DE}^{*}: 4 \mathrm{a}$

DR: A 
Table 3. Cont.

\section{e. RESULTS FROM CLINICAL PRACTICE GUIDELINES}

Year and Author

Research Question

Methodology

Results

PVC insertion technique:

Handwash with antiseptic soap and

water if visibly dirty (40-60 s) or

alcoholic-based friction (20-30 s) if

$$
\text { visibly clean. }
$$

Avoid joint areas; wrist and antecubital pit, since they have a higher incidence of

$$
\text { mechanical phlebitis. }
$$

To insert a PVC, $10-15 \mathrm{~cm}$ compressor above the puncture site, locate vein by

Guide to recommendations on nursing care of vascular accesses.
Clinical Practice Guideline

favor venous filling. alcohlic

chlorhexidine solution at $>0.5 \%$ or

aqueous chlorhexidine at $2 \%$. In cases of

hypersensitivity, use iodine solutions or

alcohol at $70 \%$. PVC is covered with

transparent sterile dressing.

$$
\text { PVC Maintenance: }
$$

Reduce connections manipulations;

handle stopcocks or bio-connectors with

hygienic hand washing and clean gloves. 
Table 3. Cont.

Torres-Muñoz et al., 2018 [4] Vascular Access Nursing Care Recommendations Guide
Clinical Practice Guideline

Selection of catheter and vein, assess objective, duration, and osmolarity of treatment, state of venous sources, and professional experience. Choose a catheter of the least length and caliber possible, without exceeding vein calibre, to allow blood passage and hemodilution of the preparations. Antiseptic on clean skin, making circles from inside to outside, and let dry.

Recommended **

- $\quad$ Evaluate insertion site daily. In case of phlebitis, this is recorded in patient history along with the degree detected. Remove blood-derived administration systems at the end of transfusion.

PVC is only changed when

clinically justified; there are no benefits on systematic change every 72-96 h.
- It is not necessary to wear sterile gloves as long as aseptic technique is guaranteed. Dressing is placed with clean gloves without touching the adhesive part and without placing tie-shaped adhesive tapes.
Category IC ** Recommended ***
Torres-Muñoz et al., 2018 [4] Vascular Access Nursing Care Recommendations Guide
Clinical Practice Guideline 
Table 3. Cont.

Torres-Muñozet Vascular Access Nursing Care Recommendations Guide
Clinical Practice Guideline
Martínez-Ortega et al., 2019 [7]
Prevention of complications related to peripheral venous catheter for vascular access.
Clinical Practice Guideline
- $\quad$ Insert PVC into upper extremities. If bleeding persists after insertion of PVC, absorbent gauze dressing may be placed and fixed until a

transparent dressing can be placed. Suture fastening will be avoided. The dressings are changed every 7 days, or if visibly soiled or damp.
Dressing change is recorded.

Before inserting a PVC, hand hygiene with alcoholic-based solution or antiseptic soap. Wear clean gloves.

Prepare skin with $2 \%$ alcoholic

chlorhexidine and allow to dry. Cover

with sterile, transparent, and

semi-permeable dressing to inspect insertion site.

Category IA **

Recommended ***

Change management systems and

connections every 4-7 days, and to

reduce risk of infection, clean access port

with antiseptic (alcoholic chlorhexidine $>0.5 \%$ or alcohol at $70 \%$ )

Remove any PVC that is not essential. 
Table 3. Cont.

Prevention of complications 2019 [7] related to peripheral venous catheter for vascular access.
Clinical Practice Guideline related to peripheral venous catheter for vascular access.

Assessment of the vascular access site, determining type of intervention, education about phlebitis for the patient and response to treatment
Select PVC based on objective, expected time of use, and known complications.

Select catheter of the smallest caliber and shortest length possible. Avoid areas of the joints (hand, wrist, and antecubital pit), with increased risk of infiltration and injury from extravasation.

Dressings will be changed every 7 days, except in pediatric patients, where risk of dislodging PVC is greater than the advantages of changing dressings. Remove PVC if signs of phlebitis,

infection, or malfunctioning appear. It is recommended to use The Visual Scale of Phlebitis Assessment (Maddox scale).

\begin{tabular}{|c|c|c|c|c|c|}
\hline $\begin{array}{c}\text { Martínez-Ortega et al., } 2019 \\
\text { [7] }\end{array}$ & $\begin{array}{l}\text { Prevention of complications } \\
\text { related to peripheral venous } \\
\text { catheter for vascular access. }\end{array}$ & Clinical Practice Guideline & $\begin{array}{l}\text { It is recommended to use split septum } \\
\text { valves against mechanical ones, which } \\
\text { have an increased risk of infection. }\end{array}$ & Category II ** & Recommended *** \\
\hline $\begin{array}{c}\text { Infusion Nurses Society, } 2016 \\
{[9]}\end{array}$ & $\begin{array}{l}\text { Assessment of the vascular } \\
\text { access site, determining type } \\
\text { of intervention, education } \\
\text { about phlebitis for the patient, } \\
\text { and response to treatment }\end{array}$ & Clinical Practice Guideline & $\begin{array}{l}\text { It is recommended to assess our patient's } \\
\text { characteristics regularly, recognize risk } \\
\text { factors for bacterial, mechanical, or } \\
\text { chemical phlebitis, and consider } \\
\text { pharmacological actions, also applying a } \\
\text { warm compress and elevating the limb. }\end{array}$ & Category IB ** & Recommended *** \\
\hline
\end{tabular}

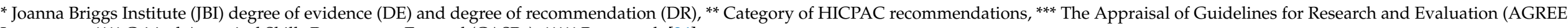
Instrument, ${ }^{* * * *}$ Critical Appraisal Skills Programme Español (CASPe), ${ }^{* * * * *}$ Berra et al. [24].
Category IB ** Recommended ${ }^{* * *}$ 
The articles are classified as nursing interventions for the prevention of phlebitis or for the treatment of phlebitis, both for nurses who apply care independently and for nurses that follow guidelines and protocols.

\subsection{Nursing Interventions for the Prevention of Phlebitis}

Management and maintenance of intravenous therapy

- $\quad$ Protocol monitoring and continuous evaluation [28,29].

- $\quad$ Records need to include date of puncture, dressings used, professional performing the procedure, date of change of PVC, puncture locations, number of puncture attempts, intravenous medication in use, change of dressing, and next check-up $[4,44]$.

- For intermittent flushing and locking of PVC, it is recommended to use saline solution (SS) before and after administration of medication by performing the positive pressure technique [4,29]. According to the Flebitis Zero project, flushing heparin is not recommended because it can cause thrombocytopenia [7]. A randomized clinical trial reflected that continuous infusion of heparin into PVCs improved the duration of permeability, reducing infusion failure and phlebitis. However, no statistically significant differences were found when heparin was used intermittently. If PVC is used to obtain a blood sample, the use of diluted heparin is indicated [43]. Double-pump syringes enable both medication and cleaning solution administration to reduce PVC manipulation and complications [40].

- $\quad$ To prevent and treat phlebitis, Aloe vera, Matricaria chamomilla, and Xianchen (composed of some components such as Fritillaria and Bletilla striata) can be used. The application of Moist Exposed Burn Ointment (MEBO) for topical treatment of burn injuries, containing sesame oil, $\beta$-sitosterol, Berberine, and other medicinal plants (Coptis chinensis, Scutellaria baicalensis, Phellodendron chinese, and Papaver somniferum) [36] is also effective.

- Remove peripheral venous catheters if the patient develops signs of phlebitis (warmth, tenderness, erythema, or palpable venous cord), infection, or a malfunctioning catheter $[7,45]$.

- Not performing a systematic catheter change every 72 to 96 h. It must be changed when clinically justified. There are no significant differences in the percentage of complications (phlebitis, occlusion...) between PVC that have been inserted less than $96 \mathrm{~h}$ and those that have been inserted for more than $96 \mathrm{~h}[4,46,47]$.

- Avoiding insertion into joint areas, wrist, and antecubital fossa, because there is a higher incidence of mechanical phlebitis related to catheter movement [4].

- $\quad$ Replacing administration systems, extension cords, and accessories with a frequency of more than $96 \mathrm{~h}$ and less than 7 days, when dirty or damaged connections are observed, and whenever there is an accidental disconnection of the circuit [4].

- Withdrawing systems of blood administration and of blood products at the end of transfusion [4].

- In adults, an upper-extremity site for catheter insertion must be used. Any catheter inserted in a lower extremity must be replaced to an upper extremity site as soon as possible [4].

- Using a 0.22-micron line filter to remove air and bacteria and small drug particles that were not properly diluted. A filter is also required when the infusion of amiodarone exceeds $24 \mathrm{~h} \mathrm{[48].}$

- $\quad$ Guiding patients and family members on signs and symptoms of phlebitis, during infusion and post-infusion after extraction of PVC [2,31]. Educating patients on the fact that ensuring proper care of PVC helps reduce risk of infection [17].

\subsection{Asepsis}

- Using alcoholic chlorhexidine solution at $>0.5 \%$ or aqueous chlorhexidine at $2 \%$. In cases of hypersensitivity, iodine solutions or alcohol at $70 \%$ may be used $[4,17]$.

- Applying antiseptics to clean skin and complying with drying times (2\% alcoholic chlorhexidine: $30 \mathrm{~s}$; non-alcoholic chlorhexidine and povidone-iodine: $2 \mathrm{~min}$ ) [4]. 
- Hygienic hand washing and usage of clean gloves for both punctures and equipment, hubs, stopcocks, and bio-connectors handling. It is not necessary to wear sterile gloves if the previously disinfected area is not touched again during the technique [4]. Using disposable tourniquets can help reduce PVC contamination rates [49].

- Minimizing handling of connectors for infusion equipment [4].

- Protecting dressing and connectors in activities that may pose a risk of contamination [4].

- High incidence of phlebitis and infection of inserted PVCs has been found in emergency areas. In these cases, it is recommended to replace the catheter within the first $48 \mathrm{~h}$ if aseptic technique could not be ensured [7,41].

\subsection{Nursing Assessment}

- Involving the patient in the choice of PVC and puncture site [2].

- Analyzing patient characteristics, prescribed medications (irritant and/or vesicant, $\mathrm{pH}$, and osmolarity), expected duration of the treatment, and other risk factors for the onset of phlebitis, before opting for a PVC $[4,30]$.

- Assessing the status of venous resources. Whenever possible, choose straight, palpable, and well-filled vessels [4].

- Keeping the PVC insertion site visible [40,45]. Developing an observation table to document the development of signs of phlebitis for early detection and decreased discomfort and pain [50].

- Previously identifying comorbidities such as diabetes mellitus due to the changes in the circulatory system caused by this disease [31].

- Asking the patient if there is pain/discomfort, heat, or burning at the insertion site [32].

\subsection{Catheter}

- Selecting the length and caliber of the catheters based on objective, expected time of use, known infectious or non-infectious complications, experience of those who insert and manage the catheter [7].

- Selecting a catheter of the least length and caliber possible, not exceeding the caliber of the chosen vessel, to allow blood to pass into the vessel and favor the hemodilution of the preparations to be infused $[4,45]$.

- Using the minimum number of three-way stopcocks. Idle ports should always be capped [4].

- Using only one of the ports of the three-way stopcock to place a bio-connector, where medication solutions and bolus will be administered. The results of a prospective experimental study indicate that using SwabCap significantly reduced connector contamination from $43.7 \%$ to $0 \%(p=0.006)$ [51]. If this cap is not available, the bio-connector is disinfected with alcoholic chlorhexidine at $>0.5 \%$ or $70 \%$ alcohol for $30 \mathrm{~s}[4,7]$.

- Teflon, silicone, or polyurethane elastomer catheters are safer than those of polyethylene, polyvinyl hydrochloride, or steel needles, which might cause tissue necrosis if extravasation occurs [43].

\subsection{Dressing}

- It is not advisable to bandage the site of the intravenous line. Sterile, transparent [45], semipermeable adhesive dressing will be used to improve visibility of the insertion site $[7,32,52]$.

- The dressing should be placed aseptically, with clean or sterile gloves, without excessively touching the adhesive layer and without placing tie-shaped adhesive tapes under the dressing. Wear sterile gloves for central and arterial devices [4].

- Changing dressings at least every 7 days, except in pediatric patients, where the risk of moving the catheter is greater than the advantages derived from changing the dressing [7]. Routine dressing change is not recommended, as it increases the risk of colonization at the puncture site [49]. 
- Replacing catheter site dressing if the dressing becomes damp, loosened, or visibly soiled [7].

- If the site is bleeding or oozing, use gauze dressing until this is resolved [4].

- Ensuring correct securement or dressing to prevent dislodgement [4].

- Softly removing dressing, without moistening the puncture site [4].

- For catheter securement, products such as CliniFix simultaneously reduce the risk of infection and trauma from cannula movement. Made with hydrocolloid adhesive, not harmful to the skin, that can remain in place for up to 7 days without affecting the integrity of the skin. In the presence of wound oozing, hydrocolloids absorb fluid and form gel to help reduce the spread of infection [42].

- Using skin glue (cyanoacrylate) at the insertion site to improve catheter securement and reduce rates of phlebitis and occlusion. Apply a drop at the insertion site and a drop under the center of the catheter, allow to dry for $30 \mathrm{~s}$, and place a dressing [33].

- Using the "I.V. House UltraDressing" in pediatric patients to increase catheter dwell time, and to protect and stabilize PIVCs [34].

\subsection{Nursing Interventions for the Treatment of Phlebitis}

Nurse as a care prescriber

- Apply alternating hot and cold compresses to decrease erythema, edema, and pain. The hot compress stimulates vasodilation by inducing optimal blood circulation and promoting a faster wound-healing process. The cold compress stimulates vasoconstriction and reduces edema [35].

- Apply compresses with $0.9 \% \mathrm{NaCl}$ to stimulate anti-inflammatory response and relieve pain, redness, swelling, and edema [35].

- Apply 10 drops (3 mL) of sesame oil (SO) twice daily for two weeks. Massage for 5 min within $10 \mathrm{~cm}$ of the place of phlebitis. Use a finger with a sterile glove to apply a rotary technique. SO contains unsaturated fatty acids (linoleic acid, oleic acid) that relieve pain by reducing prostaglandins and leukotriene. In addition, the $\mathrm{SO}$ has lignans responsible for analgesic and anti-inflammatory effects [36].

- Administer chamomile extract (2.5\%), as it has anti-inflammatory and anti-edema properties. It is the most effective in the treatment of grade II phlebitis. The use of topical chamomile showed that the incidence of phlebitis in patients treated with amiodarone decreases significantly. Aqueous chamomile extract inhibits the production of prostaglandins by the suppression of cyclooxygenase-2 (COX-2) and direct gene expression of inhibition of COX-2 enzyme activity [37].

- Apply a compress with Burow solution at a temperature between 2 and 8 degrees Celsius, and leave on for 20 min every $8 \mathrm{~h}$. This formulation has as its main component aluminium acetate, which is known for its astringent properties and ability to produce the precipitation of proteins at the topical level. Based on observed results, the Burow solution could be defined as an effective therapeutic alternative in the treatment of post-infusion phlebitis [38].

- Apply marigold ointment every $8 \mathrm{~h}$. Calendula/marigold flavonoids prevent histamine release and prostaglandin production. In addition, they inhibit blood plasma secretion in tissues, reduce the migration of white blood cells to the swelled area, and prevent the growth of bacteria and fungi by reducing capillary permeability. In one study, the application of marigold ointment decreased the severity of phlebitis in a shorter period compared to using a wet and hot compress. It is proven to have antiinflammatory and antibacterial effects. Although calendula has an anti-inflammatory effect similar to corticoids, it has none of its complications and is safe to use [39].

\subsection{Nurses Following Protocols and Guidelines}

- Topical treatments with Aloe vera or "Chamomilla Recutita" using wet compresses at 38 degrees Celsius on the affected area. Apply topical diclofenac and "Essaven" heparin gel. Other topical products such as notoginseny and $5 \mathrm{mg}$ nitroglycerin 
patch accelerate the improvement of phlebitis symptoms, as compared to heparinoid substances [6].

- Dilution of chemotherapeutic agents, immediate catheter removal, intermittent heparin washing, prophylactic antibiotics, transparent dressings, topical application of anti-inflammatory or corticosteroid agents, and application of a hot and/or wet compress are preventive and therapeutic approaches [36].

- There is no definitive treatment to prevent phlebitis; drugs such as heparin, corticosteroids, and piroxicam have been proposed as therapeutic agents [39].

In addition, Table 4 identifies the interventions found in the literature, their evidence synthesis, and their correspondence with NIC nursing interventions.

Table 4. Correspondence with NIC interventions and DE and DR analysis with JBI.

\begin{tabular}{|c|c|c|c|}
\hline Result & Interventions & $\begin{array}{l}\text { Synthesis of } \\
\text { the Evidence }\end{array}$ & NIC [20] \\
\hline \multirow{12}{*}{$\begin{array}{l}\text { Management and } \\
\text { maintenance of } \\
\text { intravenous therapy }\end{array}$} & Protocol monitoring and continuous evaluation & $\begin{array}{l}\mathrm{DE}^{*}: 3 \mathrm{c} \\
\mathrm{DR}^{*}: \mathrm{A}\end{array}$ & (6520) Health Screening \\
\hline & $\begin{array}{l}\text { Records need to include date of puncture, } \\
\text { securement used, professional performing the } \\
\text { procedure. When changing the PVC, record date, } \\
\text { site, number of puncture attempts, intravenous } \\
\text { medication in use. }\end{array}$ & $\begin{array}{l}\mathrm{DE}^{*}: 4 \mathrm{a} \\
\mathrm{DR}: \mathrm{A}\end{array}$ & $\begin{array}{l}\text { (4200) Intravenous } \\
\text { therapy (i.v.) }\end{array}$ \\
\hline & $\begin{array}{l}\text { Using sterile saline solution to secure the PVC, to } \\
\text { avoid heparin-induced thrombocytopenia. }\end{array}$ & $\begin{array}{l}\mathrm{DE}^{*}: 1 \mathrm{C} \\
\mathrm{DR}: \mathrm{A}\end{array}$ & $\begin{array}{l}\text { (2314) Intravascular } \\
\text { medication } \\
\text { administration (i.v.) }\end{array}$ \\
\hline & $\begin{array}{c}\text { For intermittent flushing and locking, perform } \\
\text { the positive pressure technique to avoid a } \\
\text { possible suction effect or backflow when } \\
\text { extracting the syringe. }\end{array}$ & $\begin{array}{l}\mathrm{DE}^{*}: 2 \mathrm{C} \\
\mathrm{DR}: \mathrm{A}\end{array}$ & $\begin{array}{l}\text { (2314) Intravascular } \\
\text { medication } \\
\text { administration (i.v.) }\end{array}$ \\
\hline & $\begin{array}{c}\text { Flushing stopcocks and hubs with normal saline } \\
\text { solution. If PVC is used to obtain a blood sample, } \\
\text { the use of diluted heparin is indicated. }\end{array}$ & $\mathrm{DR}^{*}: \mathrm{B}$ & $\begin{array}{l}\text { (4235) Phlebotomy: } \\
\text { Cannulated Vessel }\end{array}$ \\
\hline & $\begin{array}{l}\text { Using double-pump syringes to enable both } \\
\text { medication and cleaning solution administration } \\
\text { to reduce PVC manipulation and complications. }\end{array}$ & $\begin{array}{l}\text { DE: } 1 c \\
\text { DR: A }\end{array}$ & $\begin{array}{l}\text { (2314) Intravascular } \\
\text { medication } \\
\text { administration (i.v.) }\end{array}$ \\
\hline & $\begin{array}{l}\text { To prevent and treat phlebitis, use Aloe vera, } \\
\text { Matricaria chamomilla, or Xianchen. }\end{array}$ & $\begin{array}{l}\text { DE*: } 1 b \\
\text { DR: A } \\
\text { DE*: } 1 \mathrm{c} \\
\text { DR: A }\end{array}$ & $\begin{array}{l}\text { (3584) Skin care: topical } \\
\text { treatments }\end{array}$ \\
\hline & Removing any PVC that is not essential. & Category IA ** & $\begin{array}{l}\text { (4200) Intravenous } \\
\text { therapy (i.v.) }\end{array}$ \\
\hline & $\begin{array}{c}\text { Not performing a systematic catheter change } \\
\text { every } 72 \text { to } 96 \text { h. It must be changed when } \\
\text { clinically justified. }\end{array}$ & Category IB ** & $\begin{array}{l}\text { (4200) Intravenous } \\
\text { therapy (i.v.) }\end{array}$ \\
\hline & $\begin{array}{l}\text { Avoiding insertion into joint areas, wrist, and } \\
\text { antecubital fossa. }\end{array}$ & Category IA ** & $\begin{array}{l}\text { (4190) Intravenous } \\
\text { insertion (i.v.) }\end{array}$ \\
\hline & $\begin{array}{l}\text { Replacing administration systems, extension } \\
\text { cords, and accessories between } 4 \text { and } 7 \text { days. }\end{array}$ & Category IA ** & $\begin{array}{l}\text { (4200) Intravenous } \\
\text { therapy (i.v.) }\end{array}$ \\
\hline & $\begin{array}{l}\text { Guiding patients and family members on signs } \\
\text { and symptoms of phlebitis after removing the } \\
\text { catheter and at hospital discharge. }\end{array}$ & $\begin{array}{l}\mathrm{DE}^{*}: 3 \mathrm{c} \\
\mathrm{DR}^{*}: \mathrm{A} \\
\mathrm{DE}^{*}: 1^{\text {a }} \\
\mathrm{DR}: \mathrm{A}\end{array}$ & $\begin{array}{l}\text { (6610) Risk identification } \\
\text { (5510) Health education }\end{array}$ \\
\hline
\end{tabular}


Table 4. Cont.

\begin{tabular}{|c|c|c|c|}
\hline Result & Interventions & $\begin{array}{l}\text { Synthesis of } \\
\text { the Evidence }\end{array}$ & NIC [20] \\
\hline \multirow{4}{*}{ Catheter asepsis } & $\begin{array}{l}\text { Using alcoholic chlorhexidine solution at }>0.5 \% \\
\text { or aqueous chlorhexidine at } 2 \% \text { to wash skin. }\end{array}$ & Category IA ${ }^{* *}$ & $\begin{array}{l}\text { (4200) Intravenous } \\
\text { therapy (i.v.) }\end{array}$ \\
\hline & $\begin{array}{l}\text { Applying antiseptic on clean skin, making circles } \\
\text { from inside to outside, and let dry. }\end{array}$ & Category IB ** & $\begin{array}{l}\text { (4200) Intravenous } \\
\text { therapy (i.v.) }\end{array}$ \\
\hline & $\begin{array}{l}\text { Handling stopcocks, hubs, ports, and } \\
\text { bio-connectors with hygienic hand washing and } \\
\text { clean gloves. }\end{array}$ & Category IA ** & $\begin{array}{l}\text { (4200) Intravenous } \\
\text { therapy (i.v.) }\end{array}$ \\
\hline & $\begin{array}{l}\text { In cases such as those in emergency areas, } \\
\text { replace the catheter as soon as possible if aseptic } \\
\text { technique cannot be ensured. }\end{array}$ & $\begin{array}{l}\text { DE: } 1 c \\
\text { DR: A }\end{array}$ & $\begin{array}{l}\text { (4190) Intravenous } \\
\text { insertion (i.v.) } \\
\text { (4200) Intravenous } \\
\text { therapy (i.v.) }\end{array}$ \\
\hline \multirow{4}{*}{ Nursing assessment } & Involving the patient in the choice of PVC. & $\begin{array}{l}\mathrm{DE}^{*}: 3 b \\
\text { DR: } \mathrm{A}\end{array}$ & $\begin{array}{l}\text { (4190) Intravenous } \\
\text { insertion (i.v.) } \\
\text { (5510) Health education }\end{array}$ \\
\hline & $\begin{array}{c}\text { Analysing patient characteristics, prescribed } \\
\text { intravenous medications, expected duration of } \\
\text { the treatment, and other risk factors for the onset } \\
\text { of phlebitis, before opting for a PVC }\end{array}$ & $\begin{array}{l}\mathrm{DE}^{*}: 5 \mathrm{a} \\
\text { DR: } \mathrm{A}\end{array}$ & $\begin{array}{l}\text { (6610) Risk identification } \\
\text { (2314) Intravascular } \\
\text { medication } \\
\text { administration (i.v.) }\end{array}$ \\
\hline & $\begin{array}{l}\text { Assessing osmolarity of treatment and state of } \\
\text { venous sources when inserting the PVC. }\end{array}$ & Category IB ** & $\begin{array}{l}\text { (4190) Intravenous } \\
\text { insertion (i.v.) }\end{array}$ \\
\hline & $\begin{array}{l}\text { Previously identifying comorbidities such as } \\
\text { diabetes mellitus. } \\
\text { Educating to provide with knowledge on signs } \\
\text { of phlebitis and facilitate early detection and } \\
\text { minimize complications. }\end{array}$ & $\begin{array}{l}\mathrm{DE}^{*}: 4 \mathrm{a} \\
\text { DR: } \mathrm{A}\end{array}$ & $\begin{array}{l}\text { (6610) Risk identification } \\
\text { (5510) Health education }\end{array}$ \\
\hline \multirow{4}{*}{ Catheter } & $\begin{array}{l}\text { Choosing a catheter based on estimated function, } \\
\text { duration, and known complications. }\end{array}$ & $\mathrm{DR}^{*}: \mathrm{A}$ & $\begin{array}{l}\text { (4190) Intravenous } \\
\text { insertion (i.v.) }\end{array}$ \\
\hline & $\begin{array}{l}\text { Choosing a catheter of the least length and } \\
\text { caliber possible, without exceeding vein caliber. }\end{array}$ & Category IB ** & $\begin{array}{l}\text { (4190) Intravenous } \\
\text { insertion (i.v.) }\end{array}$ \\
\hline & $\begin{array}{l}\text { Using the minimum number of three-way } \\
\text { stopcocks. Idle ports should always be capped. }\end{array}$ & Category IA ** & $\begin{array}{l}\text { (4200) Intravenous } \\
\text { therapy (i.v.) }\end{array}$ \\
\hline & $\begin{array}{l}\text { Using only one of the ports of the three-way } \\
\text { stopcock to place a bio-connector, where } \\
\text { intermittent medication solutions and bolus will } \\
\text { be administered. Protect with cap infused with } \\
\text { alcoholic solution for one use or, if not possible, } \\
\text { disinfect the area with alcoholic solution for } 30 \mathrm{~s} \text {. }\end{array}$ & Category IA ** & $\begin{array}{l}\text { (4235) Phlebotomy: } \\
\text { Cannulated Vessel }\end{array}$ \\
\hline \multirow{4}{*}{ Dressing } & $\begin{array}{l}\text { Using transparent adhesive sterile dressing to } \\
\text { achieve frequent and adequate intravenous } \\
\text { inspection of the intravenous site. }\end{array}$ & Category IA ** & $\begin{array}{l}\text { (4190) Intravenous } \\
\text { insertion (i.v.) }\end{array}$ \\
\hline & $\begin{array}{c}\text { Dressings will be changed every } 7 \text { days, except } \\
\text { in pediatric patients, where risk of dislodging } \\
\text { PVC is greater than the advantages of changing } \\
\text { dressings. }\end{array}$ & Category IB $* *$ & $\begin{array}{l}\text { (4190) Intravenous } \\
\text { insertion (i.v.) }\end{array}$ \\
\hline & $\begin{array}{l}\text { Using skin glue (cyanoacrylate) at the insertion } \\
\text { site to improve catheter securement and reduce } \\
\text { rates of phlebitis and occlusion. }\end{array}$ & $\begin{array}{l}\mathrm{DE}^{*}: 1 \mathrm{c} \\
\text { DR: A }\end{array}$ & $\begin{array}{l}\text { (4190) Intravenous } \\
\text { insertion (i.v.) }\end{array}$ \\
\hline & $\begin{array}{l}\text { Using the "I.V. House UltraDressing" in pediatric } \\
\text { patients to increase catheter dwell time, and to } \\
\text { protect and stabilize PIVCs. }\end{array}$ & $\begin{array}{l}\mathrm{DE}^{*}: 1 \mathrm{a} \\
\text { DR: } \mathrm{A}\end{array}$ & $\begin{array}{l}\text { (4190) Intravenous } \\
\text { insertion (i.v.) }\end{array}$ \\
\hline
\end{tabular}


Table 4. Cont.

\begin{tabular}{|c|c|c|c|}
\hline Result & Interventions & $\begin{array}{l}\text { Synthesis of } \\
\text { the Evidence }\end{array}$ & NIC [20] \\
\hline \multirow{7}{*}{ Nurse as a care prescriber } & $\begin{array}{l}\text { Applying alternating hot and cold compresses to } \\
\text { decrease erythema, edema, and pain. }\end{array}$ & $\begin{array}{l}\mathrm{DE}^{*}: 3 \mathrm{c} \\
\mathrm{DR}: \mathrm{A}\end{array}$ & $\begin{array}{l}\text { (1380) Heat/Cold } \\
\text { Application }\end{array}$ \\
\hline & $\begin{array}{l}\text { Applying compresses with } 0.9 \% \mathrm{NaCl} \text { to } \\
\text { stimulate anti-inflammatory response and } \\
\text { relieve pain, redness, swelling, and oedema. }\end{array}$ & $\begin{array}{l}\mathrm{DE}^{*}: 2 \mathrm{c} \\
\text { DR: A }\end{array}$ & $\begin{array}{l}\text { (1380) Heat/Cold } \\
\text { Application }\end{array}$ \\
\hline & $\begin{array}{l}\text { Applying } 10 \text { drops }(3 \mathrm{~mL}) \text { of sesame oil }(\mathrm{SO}) \\
\text { twice daily for two weeks. Massage for } 5 \mathrm{~min} \text {. }\end{array}$ & $\begin{array}{l}\text { DE*: } 1 \mathrm{c} \\
\text { DR: A }\end{array}$ & $\begin{array}{l}\text { (3584) Skin care: } \\
\text { topical treatments }\end{array}$ \\
\hline & $\begin{array}{l}\text { Applying Moist Exposed Burn Ointment } \\
\text { (MEBO) for topical treatment of burn injuries. }\end{array}$ & $\begin{array}{l}\text { DE*: } 1 \mathrm{a} \\
\text { DR: } A\end{array}$ & $\begin{array}{l}\text { (3584) Skin care: } \\
\text { topical treatments }\end{array}$ \\
\hline & $\begin{array}{l}\text { Administering chamomile extract }(2.5 \%) \text {, as it } \\
\text { has anti-inflammatory and } \\
\text { anti-edema properties. }\end{array}$ & $\begin{array}{l}\mathrm{DE}^{*}: 1 b \\
\text { DR: } \mathrm{A}\end{array}$ & $\begin{array}{l}\text { (3584) Skin care: } \\
\text { topical treatments }\end{array}$ \\
\hline & $\begin{array}{l}\text { Applying marigold ointment every } 8 \mathrm{~h} \text { for } \\
\text { anti-inflammatory effect. }\end{array}$ & $\begin{array}{l}\mathrm{DE}^{*}: 1 \mathrm{c} \\
\text { DR: A }\end{array}$ & $\begin{array}{l}\text { (3584) Skin care: } \\
\text { topical treatments }\end{array}$ \\
\hline & $\begin{array}{l}\text { Applying a compress with Burow solution at a } \\
\text { temperature between } 2 \text { and } 8 \text { degrees Celsius, } \\
\text { and leave on for } 20 \text { min every } 8 \mathrm{~h} \text {. }\end{array}$ & $\begin{array}{l}\mathrm{DE}^{*}: 3 \mathrm{c} \\
\text { DR: A }\end{array}$ & $\begin{array}{l}\text { (3584) Skin care: } \\
\text { topical treatments }\end{array}$ \\
\hline \multirow[b]{3}{*}{$\begin{array}{l}\text { Nurse following protocols } \\
\text { and guidelines }\end{array}$} & $\begin{array}{l}\text { Applying of anti-inflammatory or corticosteroid } \\
\text { agents, and application of a hot and/or } \\
\text { wet compress. }\end{array}$ & $\begin{array}{l}\mathrm{DE}^{*}: 1 \mathrm{a} \\
\text { DR: } \mathrm{A}\end{array}$ & $\begin{array}{l}\text { (3584) Skin care: } \\
\text { topical treatments }\end{array}$ \\
\hline & $\begin{array}{l}\text { Using corticosteroids and piroxicam to } \\
\text { prevent phlebitis. }\end{array}$ & $\begin{array}{l}\mathrm{DE}^{*}: 1 \mathrm{c} \\
\text { DR: A } \\
\text { DE*: } 1^{\text {a }} \\
\text { DR: A }\end{array}$ & $\begin{array}{l}\text { (2316) Medication } \\
\text { Administration: Skin }\end{array}$ \\
\hline & $\begin{array}{l}\text { Applying topical treatments with aloe vera or } \\
\text { "Chamomilla Recutita" using wet compresses at } \\
38 \text { degrees Celsius on the affected area. } \\
\text { Apply topical diclofenac and "Essaven" heparin } \\
\text { gel for the treatment of phlebitis. } \\
\text { Topical products such as notoginseny and } 5 \mathrm{mg} \\
\text { nitroglycerin patch accelerate the improvement } \\
\text { of phlebitis symptoms, as compared to } \\
\text { heparinoid substances. }\end{array}$ & $\begin{array}{l}\mathrm{DE}^{*}: 1 \mathrm{a} \\
\text { DR: } \mathrm{A}\end{array}$ & $\begin{array}{l}\text { (2316) Medication } \\
\text { Administration: Skin } \\
\text { (3584) Skin care: } \\
\text { topical treatments }\end{array}$ \\
\hline
\end{tabular}

* Joanna Briggs Institute (JBI) degree of evidence (DE) and degree of recommendation (DR), ${ }^{* *}$ Category of HICPAC recommendations.

\section{Discussion}

The objective of this review was to identify available evidence on nursing interventions for the prevention and treatment of phlebitis secondary to the insertion of a peripheral venous catheter.

For the prevention of phlebitis, the greatest evidence found regarding asepsis is to use $>0.5 \%$ chlorhexidine preparation with alcohol or $2 \%$ aqueous chlorhexidine, perform hygienic hand washing, and use clean gloves to handle connections and stopcocks (category AI). Regarding the maintenance of PVC, the interventions with the greatest evidence (category IA) are replacing extensions and administration sets between 4 and a maximum of 7 days if they are not loosened or soiled, and using the fewest three-way stopcocks, one of the ports with a bio-connector, and having the others capped [4]. Actions that promote the efficacy and safety of intravenous therapy include maintenance of access, infusion control, verification of signs of phlebitis during saline solution replacement and medication administration, and constant monitoring $[53,54]$. It is recommended to remove any catheter that is not essential (Category IA) [7]. Once discharged from hospital, it will be necessary to warn the patient about signs of phlebitis after PVC removal [2] (DE 1a). 
Regarding the dressing, the greatest evidence obtained is the use of "IV House UltraDressing" in pediatric patients to increase dwell time and stabilize the catheter [34] (DE IA). The dressing must be sterile, transparent, and semi-permeable for continuous visual inspection of the catheter site [7] (Category IA). A novel technique is the use of medical grade cyanoacrylate for catheter securement to reduce rates of phlebitis [33] (DE 1c).

Vein quality control through palpation and visual inspection can prevent phlebitis as well as the nurse's duration of hand hygiene and the clinical experience [55]. Regarding the choice of veins, a controversy has been found, as some studies recommend the forearm as it has a larger diameter and this reduces rates of phlebitis in the region, but there are many others that claim that this region should be avoided, in addition to the joints and wrist areas (category IA), for having a higher incidence of mechanical phlebitis related to catheter movement $[4,56]$. A review of the literature concluded that veins from the antecubital region are associated with lower rates of phlebitis, as compared to veins in the hands. Therefore, although the back of the hand is considered an easily accessible venous place, it is not indicated for prolonged venous therapy, and nurses are believed to need to be trained in carrying out alternatives such as jugular vein venipuncture that has very low rates of prevalence of phlebitis [44].

Although some studies, such as the one conducted by Circolini et al. (cited in Wei et al. [57]), in which Cox's analysis was used, showed that as the PVC's dwell time increased by $24 \mathrm{~h}$, the risk of phlebitis also did so with an odds ratio of 1.05. Webster et al.'s [46] team concluded in their clinical trial review that the catheter should be removed only when clinically indicated, evaluating at every new shift to identify signs of phlebitis $[46,57,58]$ early.

There are higher rates of phlebitis when larger caliber catheters are used, as they increase attraction to the vessel wall, so the smallest possible length and caliber catheters (Category IB) are recommended [4,56].

The nurse's clinical judgment regarding the selection of a PVC should also involve assessing comfort, anxiety, and restrictions in the patient's day-to-day activities. The number of venipuncture attempts is one of the quality indicators and shows patient satisfaction for its sensory impact [59].

For the control and management of intravenous therapy, nurses should carry out a protocol that includes recording all aspects related to the catheter and its maintenance (DE 4a and DR A) [28].

According to the studies consulted, the data show a higher proportion of complications in peripheral venous catheters among women $(p=0.0300)$, patients 85 years of age or older as compared to those under $65(p=0.0500)$, and when puncturing the forearm region as compared to other regions $(p \leq 0.0001)$ [60].

Regarding saline flush, the effectiveness and safety of a solution of $0.9 \%$ of sodium chloride was compared with heparin saline solution, and it was concluded that both agents are equally effective and safe [14]. However, flushing PVC with normal saline prevents the accumulation of bacteria, proteins, and platelets suspended in plasma; therefore, saline flush prevents and reduces phlebitis [13] (DE 1c).

It is necessary to check that the prescription of intravenous medication can be administered peripherally, as many of these drugs are irritating. Regular evaluation is key to the prevention and early detection of intravenous complications (DE 5a) [30,61].

In case the patient has phlebitis, nursing interventions with more evidence in their application are Moist Exposed Burn Ointment (MEBO) for topical treatment of burn injuries, Aloe vera, chamomilla recutita in wet compresses, topical diclofenac, "Essaven" heparin gel, notoginseny, and $5 \mathrm{mg}$ nitroglycerin patch and anti-inflammatory or corticosteroids in a hot or wet compress (DE 1a) $[6,36]$. On the other hand, the application of marigold ointment, piroxicam, and sesame oil has an evidence level of 1C [36,39].

Some limitations of this bibliographic review are the little available evidence on the use of Burow's solution as a treatment for phlebitis, despite its usual use in hospitals. This review may contain limitations inherent to the search and selection process. Therefore, we believe that further research and systematic review of the findings is needed. 


\section{Conclusions}

In conclusion, this review includes evidence-based interventions for the prevention and treatment of phlebitis associated to the venous catheter. The need for nursing training on the latest available evidence regarding the use and management of venous catheters is highlighted. It is important that hospitals implement projects such as "Flebitis Zero" so that nurses can rely and base their knowledge on them, thus providing quality care to patients.

Author Contributions: Conceptualization, A.G.-S., M.B.S.-G., M.E.C.-P., J.Á.R.-G., J.G.-S. and G.D.C.; Data curation, A.G.-S., M.B.S.-G. and G.D.-C.; Formal analysis, A.G.-S., M.B.S.-G., M.E.C.-P., J.Á.R.-G., J.G.-S. and G.D.-C.; Investigation, A.G.-S., M.B.S.-G., M.E.C.-P., J.Á.R.-G., J.G.-S. and G.D.C.; Methodology, A.G.-S., M.B.S.-G., M.E.C.-P., J.Á.R.-G., J.G.-S. and G.D.-C.; Project administration, A.G.-S., M.B.S.-G. and G.D.-C.; Resources, A.G.-S., M.B.S.-G., M.E.C.-P., J.Á.R.-G., J.G.-S. and G.D.-C.; Software, A.G.-S., M.B.S.-G., M.E.C.-P., J.Á.R.-G., J.G.-S. and G.D.-C.; Supervision, A.G.-S., M.B.S.-G., M.E.C.-P., J.Á.R.-G., J.G.-S. and G.D.-C.; Validation, A.G.-S., M.B.S.-G., M.E.C.-P., J.Á.R.-G., J.G.-S. and G.D.-C.; Visualization, A.G.-S., M.B.S.-G., M.E.C.-P., J.Á.R.-G., J.G.-S. and G.D.-C.; Writing-original draft, A.G.-S., M.B.S.-G., M.E.C.-P., J.Á.R.-G., J.G.-S. and G.D.-C.; Writing-review and editing, A.G.-S., M.B.S.-G., M.E.C.-P., J.Á.R.-G., J.G.-S. and G.D.-C. All authors have read and agreed to the published version of the manuscript.

Funding: This research received no external funding.

Institutional Review Board Statement: Not applicable.

Informed Consent Statement: Not applicable.

Data Availability Statement: All data is available within this article.

Acknowledgments: We would like to thank to the School of Nursing Nuestra Señora de Candelaria of Tenerife, Spain, its teachers and board of directors, for their collaboration for the development of this Final Degree Project, as well as for their educational and socializing work.

Conflicts of Interest: The authors declare no conflict of interest.

\section{References}

1. Urbanetto, J.S.; Peixoto, C.G.; May, T.A. Incidencia de flebitis durante el uso y después de la retirada de catéter intravenoso periférico. Rev. Latino-Am. Enfermagem 2016, 24, e2746. [CrossRef]

2. Salgueiro-Oliveira, A.S.; Basto, M.L.; Braga, L.M.; Arreguy-Sena, C.; Melo, M.N.; Parreira, P.M. Nursing practices in peripheral venous catheter: Phlebitis and patient safety. Texto Contexto-Enferm 2019, 28, e20180109. [CrossRef]

3. Enes, S.M.S.; Opitz, S.P.; Faro, A.R.M.d.C.d.; Pedreira, M.d.L.G. Phlebitis associated with peripheral intravenous catheters in adults admitted to hospital in the Western Brazilian Amazon. Rev. Esc. Enferm. USP 2016, 50, 263-271. [CrossRef] [PubMed]

4. Torres-Muñoz, R.; Marín-Navarro, L.; Gallego-Sánchez, J.C. Cuidados de Enfermería en los Accesos Vasculares. Guía De recomendaciones. Complejo Hospitalario Universitario de Badajoz. Área de Salud de Badajoz. 2018. Available online: https:/ / www.areasaludbadajoz.com/Calidad_y_Seguridad_2016/Cuidados_enfermeria_accesos_vasculares.pdf (accessed on 12 December 2020).

5. Tork-Torabi, M.; Namnabati, M.; Allameh, Z.; Talakoub, S. Vancomycin Infusion Methods on Phlebitis Prevention in Children. Iran. J. Nurs. Midwifery Res. 2019, 24, 432-436. [CrossRef]

6. Martín-Gil, B.; Fernández-Castro, M.; López-Vallecillo, M.; Peña-García, I. Efectividad del tratamiento tópico de la flebitis secundaria a la cateterización periférica: Una revisión sistemática. Enferm. Glob. 2017, 16, 491-507. [CrossRef]

7. Martínez-Ortega, C.; Suárez Mier, B.; Cantero, M.; Llinás, M.; Plan Nacional Resistencia Antibióticos. Prevención de Complicaciones Relacionadas con Accesos Vasculares de Inserción Periférica. Programa Flebitis Zero. Ministerio de Sanidad, Consumo y Bienestar Social. Agencia Española de Medicamentos y Productos Sanitarios. 2019. Available online: http: / / www.resistenciaantibioticos.es/es/system/files/content_images/programa_flebitis_zero.pdf (accessed on 12 February 2021).

8. Ray-Barruel, G.; Cooke, M.; Mitchell, M.; Chopra, V.; Rickrad, C.M. Implementing the I-DECIDED clinical decision-making tool for peripheral intravenous catheter assessment and safe removal: Protocol for an interrupted time-series study. BMJ Open 2018, 8, e021290. [CrossRef]

9. Infusion Nurses Society. Infusion Nursing Standards of Practice. J. Infus. Nurs. 2016, 36, 1-159. 
10. Ortiz del Río, C.A.; Pérez de la Blanca, E.B.; Buzón Barrera, M.L.; Calderón Sandubete, E.; Carrero Caballero, M.C.; Carrión Camacho, M.R.; Luna Rodríguez, M.E.d.; García Aguilar, R.; García Díez, R.; García Fernández, F.P.; et al. Guía de Práctica Clínica Sobre Terapia Intravenosa con Dispositivos no Permanentes en Adultos. Ministerio de Sanidad, Servicios Sociales e Igualdad. Agencia de Evaluación de Tecnologías Sanitarias de Andalucía (AETSA). 2014. Available online: https://www.aetsa. org/publicacion/guia-de-practica-clinica-sobre-terapia-intravenosa-con-dispositivos-no-permanentes-en-adultos/ (accessed on 12 February 2021).

11. Nickel, B. Peripheral Intravenous Access: Applying Infusion Therapy Standards of Practice to Improve Patient Safety. Crit. Care Nurse 2019, 39, 61-71. [CrossRef]

12. Atay, S.; Sen, S.; Cukurlu, D. Phlebitis-related peripheral venous catheterization and the associated risk factors. Niger. J. Clin. Pract. 2018, 21, 827-831. [CrossRef]

13. Eghbali-Babadi, M.; Ghadiriyan, R.; Hosseini, S.M. The effect of saline lock on phlebitis rates of patients in cardiac care units. Iran. J. Nurs. Midwifery Res. 2015, 20, 496-501. [CrossRef]

14. Milutinović, D.; Simin, D.; Zec, D. Risk factor for phlebitis: A questionnaire study of nurses' perception. Rev. Lat. Am. Enferm. 2015, 23, 677-684. [CrossRef]

15. Furlan, M.S.; Costa-Lima, A.F. Direct cost of procedures for phlebitis treatment in an Inpatient Unit. Rev. Esc. Enferm. USP 2020, 54, e03647. [CrossRef]

16. Chiu, P.C.; Lee, Y.H.; Hsu, H.T.; Fneg, Y.T.; Lu, I.C.; Chiu, S.L.; Cheng, K.I. Establish a perioperative check forum for peripheral intravenous access to prevent the occurrence of phlebitis. Kaohsiung J. Med. Sci. 2015, 31, 215-221. [CrossRef]

17. Osti, C.; Khadka, M.; Wosti, D.; Gurung, G.; Zhao, Q. Knowledge and practice towards care and maintenance of peripheral intravenous cannula among nurses in Chitwan Medical College Teaching Hospital, Nepal. Nurs. Open 2019, 6, 1006-1012. [CrossRef]

18. Ministerio de Ciencia e Innovación. Orden Cin/2134/2008, de 3 de Julio, Por la Que se Establecen los Requisitos para la Verificación de los Títulos Universitarios Oficiales que Habiliten para el Ejercicio de la Profesión de Enfermero. BOE Num 174, de 19 de Julio de 2008. Available online: https:/ / www.boe.es/eli/es/o/2008/07/03/cin2134 (accessed on 18 May 2021).

19. Herdman, T.H.; Kamitsuru, S. (Eds.) NANDA International Nursing Diagnoses: Definition and Clasification 2018-2020, 11th ed.; Thieme Medical Publishers Inc.: New York, NY, USA, 2017.

20. Butcher, H.K.; Bulechek, G.M.; Dochrterman, J.M.; Wagner, C. Clasificación de Intervenciones de Enfermería (NIC), 7th ed.; Elsevier: Barcelona, Spain, 2018.

21. Arksey, H.; O’Malley, L. Scoping studies: Towards a methodological framework. Int. J. Soc. Res. Methodol. 2005, 8, 19-32. [CrossRef]

22. Moher, D.; Liberati, A.; Tetzlaff, J.; Altman, D.G.; The PRISMA Group. Preferred Reporting Items for Systematic Reviews and Meta-Analyses: The PRISMA Statement. PLoS Med. 2009, 6, e1000097. [CrossRef]

23. Santamaría-Olmo, R. Programa de habilidades en Lectura Crítica Español (CASPe). Nefroplus 2017, 9, $100-101$.

24. Berra, S.; Elorza-Ricart, J.M.; Estrada, M.D.; Sánchez, E. Instrumento para la lectura crítica y la evaluación de estudios epidemiológicos transversales. Gac. Sanit. 2008, 22, 492-497. [CrossRef]

25. Levac, D.; Colquhoun, H.; O’Brien, K.K. Scoping studies: Advancing the methodology. Implement. Sci. 2010, 5, 69. [CrossRef]

26. Flórez-Gómez, I.D.; Montoya, D.C. Las guías de práctica clínica y el instrumento AGREE II. Rev. Colomb. Ppsiquiat. 2011, 40, 563-576. [CrossRef]

27. Manterola, C.; Asenjo-Lobos, C.; Otzen, T. Jerarquización de la evidencia: Niveles de evidencia y grados de recomendación de uso actual. Rev. Chil. Infectol. 2014, 31, 705-718. [CrossRef]

28. Jordan, Z.; Lockwood, C.; Munn, Z.; Aromataris, E. The update Joanna Briggs Institute Model of Evidence Based Healthcare. Int. J. Evid. Based Healthc. 2019, 17, 58-71. [CrossRef]

29. Reichembach-Danski, M.T.; Mingorance, P.; Athanasio-Johann, D.; Adami-Vayego, S.; Lind, J. Incidence of local complications and risk factors associated with peripheral intravenous catheter in neonates. Rev. Esc. Enferm. USP 2016, 50, 22-28. [CrossRef] [PubMed]

30. Braga, L.M.; Parreira, P.M.; Salgueiro-Oliveira, A.S.; Mendes-Mónico, L.S.; Arreguy-Sena, C.; Henriques, M.A. Flebitis e infiltración: Traumas vasculares asociados al catéter venoso periférico. Rev. Lat. Am. Enfermagem 2018, 26, e3002. [CrossRef]

31. Rosário-Pereira, M.S.; de Oliveria-Cunha, A.T.; Almeida-Lima, E.F.; Ferreira-Santos, T.F.; Batista-Portugal, F. La Seguridad del paciente en el contexto de las flebitis notificadas en un hospital universitario. Rev. Epidemiol. Controle Infecção 2019, 9, 1-7. [CrossRef]

32. Lim, E.Y.P.; Wong, C.Y.W.; Kek, L.K.; Suhairi, S.S.B.M.; Yip, W.K. Improving the Visibility of Intravenous (IV) Site in Pediatric Patients to Reduce IV Site Related Complications-An Evidence-based Utilization Project. J. Pediatr. Nurs. 2018, 41, e39-e45. [CrossRef]

33. Bugden, S.; Shean, K.; Scott, M.; Mihala, G.; Clark, S.; Johnstone, C.; Fraser, J.F.; Rickard, C.M. Skin Glue Reduces the Failure Rate of Emergency Department-Inserted Peripheral Intravenous Catheters: A Randomized Controlled Trial. Ann. Emerg. Med. 2016, 68, 196-201. [CrossRef]

34. Büyükyılmaz, F.; Şahiner, N.C.; Cağlar, S.; Eren, H. Effectiveness of an Intravenous Protection Device in Pediatric Patients on Catheter Dwell Time and Phlebitis Score. Asian Nurs. Res. 2019, 13, 236-241. [CrossRef] 
35. Annisa, F.; Nurhaeni, N.; Wanda, D. Warm Water Compress as an Alternative for Decreasing the Degree of Phlebitis. Compr. Child Adolesc. Nurs. 2017, 40 (Suppl. 1), 107-113. [CrossRef]

36. Shamloo, M.B.B.; Nasiri, M.; Maneiy, M.; Dorchin, M.; Mojab, F.; Bahrami, H.; Naseri, M.S.; Kiarsi, M. Effects of topical sesame (Sesamum indicum) oil on the pain severity of chemotherapy-induced phlebitis in patients with colorectal cancer: A randomized controlled trial. Complement Ther. Clin. Pract. 2019, 35, 78-85. [CrossRef] [PubMed]

37. Sharifi-Ardani, M.; Yekefallah, L.; Asefzadeh, S.; Nassiri-Asl, M. Efficacy of topical chamomile on the incidence of phlebitis due to an amiodarone infusion in coronary care patients: A double-blind, randomized controlled trial. J. Integr. Med. 2017, 15, 373-378. [CrossRef]

38. García-Quintanilla, L.; Otero-Barreiro, M.; González-Barcia, M.; Virgós-Lamela, A.; Rodríguez-Prada, M.; Lamas, M.; FernándezFerreiro, A. Estudio de la Utilización, Eficacia y Seguridad de la Solución de Burow en el tratamiento de la flebitis. Rev. Ofil Ibero Lat. Am. J. Health Syst. Pharm. 2018, 28, 199-202.

39. Jourabloo, N.; Nasrabadi, T.; Ebrahimi-Abyaneh, E. Comparing the effect of warm moist compress and Calendula ointment on the severity of phlebitis caused by 50\% dextrose infusion: A clinical trial. Med. Surg. Nurs. 2017, 6, 21-26.

40. Parreira, P.; Sousa, L.B.; Marques, I.A.; Santos-Costa, P.; Braga, L.M.; Cruz, A.; Salgueiro-Oliveira, A. Double-chamber syringe versus classic syringes for peripheral intravenous drug administration and catheter flushing: A study protocol for a randomised controlled trial. Trials 2020, 21, 78. [CrossRef]

41. Pérez-Granda, M.J.; Bouza, E.; Pinilla, B.; Cruces, R.; González, A.; Millán, J.; Guembe, M. Randomized clinical trial analyzing maintenance of peripheral venous catheters in an internal medicine unit: Heparin vs. saline. PLoS ONE 2020, 15, e0226251. [CrossRef]

42. Higgingson, R. IV cannula securement: Protecting the patient from infection. Br. J. Nurs. 2015, 24, S23-S28. [CrossRef]

43. Chau, J.; Pellowe, C.; Instituto Joanna Briggs. Manejo de los dispositivos intravasculares periféricos. Best Pract. 2008, 12, 1-4, ISSN 1329-1874.

44. Da Silva-Oliveira, E.C.; Barros-de Oliveira, A.P.; de Oliveira, R.C. Caracterización de flebitis notificada a la gestión de riesgos en la red centinela hospitalaria. Rev. Baiana Enferm. 2016, 1-9. [CrossRef]

45. Mattox, E.A. Complications of Peripheral Venous Access Devices: Prevention, Detection, and Recovery Strategies. Crit. Care Nurse 2017, 37, e1-e14. [CrossRef]

46. Webster, J.; Osborne, S.; Rickard, C.M.; Marsh, N. Clinically-indicated replacement versus routine replacement of peripheral venous catheters. Cochrane Database Syst. Rev. 2019, 23, CD007798. [CrossRef]

47. Gilton, L.; Seymour, A.; Baker, R.B. Changing Peripheral Intravenous Catheter Sites When Clinically Indicated: An Evidence-Based Practice Journey. Worldviews Evid. Based Nurs. 2019, 16, 418-420. [CrossRef] [PubMed]

48. Oragano, C.A.; Patton, D.; Moore, Z. Phlebitis in Intravenous Amiodarone Administration: Incidence and Contributing Factors. Crit. Care Nurs. 2019, 39, 1-12. [CrossRef] [PubMed]

49. Parreira, P.; Serambeque, B.; Costa, P.S.; Mónico, L.S.; Oliveira, V.; Sousa, L.B.; Gama, F.; Bernardes, R.A.; Adriano, D.; Marques, I.A.; et al. Impact of an Innovative Securement Dressing and Tourniquet in Peripheral Intravenous Catheter-Related Complications and Contamination: An Interventional Study. Int. J. Environ. Res. Public Health 2019, 16, 3301. [CrossRef]

50. Mandal, A.; Raghu, K. Study on incidence of phlebitis following the use of peripheral intravenous catheter. J. Fam. Med. Prim. Care 2019, 8, 2827-2831. [CrossRef]

51. Gutiérrez-Nicolás, F.; Nazco-Casariego, G.J.; Viña-Romero, M.M.; González-García, J.; Ramos-Diaz, R.; Perez-Perez, J.A. Reducing the degree of colonisation of venous access catheters by continuous passive disinfection. Eur. J. Hosp. Pharm. 2016, 23, 131-133. [CrossRef]

52. Corley, A.; Ullman, A.J.; Mihala, G.; Ray-Barruel, G.; Ray-Barruel, G.; Alexandrou, E.; Rickard, C.M. Peripheral intravenous catheter dressing and securement practice is associated with site complications and suboptimal dressing integrity: A secondary analysis of 40,637 catheters. Int. J. Nurs. Stud. 2019, 100. [CrossRef]

53. Lemos-Alves, J.; Mendes-Rodrígues, C.; Velloso-Antunes, A. Prevalence of Phlebitis in a Clinical Inpatient Unit of a Highcomplexity Brazilian University Hospital. Rev. Bras. Ciências Saúde 2018, 22, 231-236.

54. Roman-Ros, A.C.; Ramos-Oliveira, D.; Debon, R.; Scaratti, M. Intravenous therapy in hospitalized older adults: Care evaluation. Cogitare Enferm 2017, 2, e49989.

55. Lee, S.; Kim, K.; Kim, J.S. A Model of Phlebitis Associated with Peripheral Intravenous Catheters in Orthopedic Inpatients. Int. J. Environ. Res. Public Health. 2019, 16, 3412. [CrossRef]

56. Loureiro-Buzatto, L.; Pinna-Massa, G.; Sorgini-Peterlini, M.A.; Yamaguchi-Whitaker, I. Factors associated with phlebitis in elderly patients with intravenous infusion. Acta. Paul. Enferm. 2016, 29, 260-266. [CrossRef]

57. Wei, T.; Li, X.; Yue, Z.; Chen, Y.; Wang, Y.; Yuan, Z.; Lin, Q.; Tan, Y.; Peng, S.; Li, X. Catheter Dwell Time and Risk of Catheter Failure in Adult Patients With Peripheral Venous Catheters. J. Clin. Nurs. 2019, 28, 4488-4495. [CrossRef]

58. Urbanetto, J.S.; Minuto-Muniz, F.O.; Martis da Silva, R.; Christo de Freitas, A.P.; Ribeiro de Oliveira, A.P.; Ramos dos Santos, J.C. Incidence of phlebitis and post-infusion phlebitis in hospitalised adults. Rev. Gaúcha Enferm. 2017, 38, e58793.

59. Braga, L.M.; Salgueiro-Oliveira, A.S.; Pereira Henriques, M.A.; Arreguy-Sena, C.; Pianetti Albergaria, V.M.; Dinis-Parreira, P.M. Cateterismo venoso periférico: Comprensión y evaluación de las prácticas de enfermería. Texto Context-Enferm. 2019, 28, e20180018. [CrossRef] 
60. Reichembach Danski, M.T.; Johann, D.A.; Vayego, S.A.; Rodrigues-Lemes de Oliveira, G.; Lind, J. Complications related to the use of peripheral venous catheters: A randomized clinical trial. Acta. Paul. Enferm. 2016, 29, 84-92.

61. Ray-Barruel, G. Infection Prevention: Peripheral Intravenous Catheter Assessment and Care. Aust. Nurs. Midwifery J. 2017, $24,34$. 